\title{
УДОСКОНАЛЕННЯ ПРАКТИЧНОЇ РОБОТИ СТУДЕНТІВ НА КАФЕДРІ ВНУТРІШНЬОЇ МЕДИЦИНИ № 1
}

\author{
Н. І. Ярема, Л. В. Наумова, А. О. Боб \\ ДВНЗ “Тернопільський державниймедичнийуніверситет імені І. Я. Горбачевського МОЗ Украӥни” \\ IMPROVEMENT OF STUDENTS' PRACTICAL WORK ON THE \\ DEPARTMENT OF INTERNAL MEDICINE № 1
}

\author{
N. I. Yarema, L.V. Naumova, A. O. Bob \\ SHEI "Ternopil State Medical University by I. Ya. Horbachevsky of MPH of Ukraine"
}

\begin{abstract}
У статті наводяться дані стосовно удосконалення керованої практичної роботи студентів. Ефективність практичної роботи студентів забезпечується кейс-технологіями та інтранет-технологіями. Пізнавальний цикл практичної роботи здійснюється самостійно студентами та за консультативної участі викладача.
\end{abstract}

Data of the improvement of the guided practical work of students was shown in the article. Efficacy of their work out of classes is provided by using of such technologies as keis and intranet. Knowledge cycle of practical work is provided by students' selfwork and teacher's consultative participation.

Вступ. Консолідація українського суспільства в європейське освітнє товариство грунтується на удосконаленні новітніх технологій навчання із урахуванням кращих досягнень вітчизняної педагогічної науки та зарубіжної медичної освіти $[1,2]$. У цьому контексті в педагогіці вважається, що вирішальним $€$ спрямування студентів на самостійне набуття ними знань із різних джерел інформації та оволодіння якомога більшим арсеналом практичних навичок [4]. Це випливає із концепції Я. А. Коменського [5], у якій вказується, що вчитель повинен менше вчити, а учень більше вчитися. Проте медична освіта має свої особливості. Якщо раніше студент вважався головним суб'єктом навчальної діяльності викладача, то на сьогодні вся дидактична система спрямовується на вибір студентом самостійного оволодіння знаннями, методами навчання і прийняття рішень $[3,6]$. Як кожен метод навчання, практика - це багатомірне явище, результативність якого залежить від методичного забезпечення [6].

Основна частина. Згідно з концепцією розвитку університету, однією з основних цілей навчання студентів на клінічних кафедрах $\epsilon$ здобуття ними наукових даних не тільки із наявних підручників і посібників, але й з електронних носіїв інформації у тісному поєднанні із оволодінням практичними прийомами роботи лікаря. 3 метою удосконалення роботи сту-

() Н. І. Ярема, Л. В. Наумова, А. О. Боб дентів на кафедрі внутрішньої медицини № 1 застосовують комплекс кейс-технології, інтранет-технології та інтернет-технології. Кейс-технологія передбачає дистанційне забезпечення студента інформацією про послідовність освоєння модулів, навчальними програмами і неметодичними (інформаційними) матеріалами, а інтранет-технологія забезпечує доступ в інтранет-систему як студента, так і викладача до інформаційних ресурсів, а саме: матеріалів підготовки до лекцій, презентації лекцій, підготовки до практичних занять, переліку практичних навичок, віртуальних програм. Оснащення кафедри комп'ютерами, крім використання кейс- та інтранет-технологій, дає можливість за допомогою інтернет-технологій розвивати у студентів технічні навички і уміння користуватися пошуковими системами з метою здобуття новітніх знань.

Методичні матеріали, розміщені на Web-сторінці кафедри, забезпечують дистанційну управляючу i консультативну функції.

При роботі студентів із методичними матеріалами, за даними О. І. Щоголєвої, формується уміння виявляти те, що вимагається від них на основі даного їм алгоритму, і спрямувань на вказану діяльність, яка міститься в умові завдання. Студенти при цьому використовують, крім відомих підручників і посібників, матеріали підготовки до практичних занять, які розміщені на Web-сторінці кафедри. Особливістю сторінки кафедри $€$ те, що на ній подається найнові- 
ша інформація з даної теми заняття, а також для зручності студентів, окремим кольором виділяються ті фрагменти теоретичного матеріалу, що є обов'язковими для засвоєння.

Невід'ємною частиною практичного заняття є формування у студентів знань і навиків за принципом “роби, як я”. Це досягається шляхом розв'язання студентами ситуаційних задач, вивчення результатів додаткових лабораторно-інструментальних методів дослідження. Новинкою при підготовці до практичних занять $€$ освоєння віртуальних програм. Окрім цього реалізується концепція необхідності формування у студента-медика навиків творчої діяльності, адже кожен пацієнт - це окрема нестандартна задача, яка вимагає для ії̈ вирішення наукового підходу. Цей дидактичний захід вирішується вивченням студентом нетипових спостережень із практики, а також освоєнням алгоритму написання історії хвороби в кінці кожного змістового модуля.

Кінцевим етапом роботи студентів $є$ самоконтроль. Студент користується системою Moodle, яка впроваджена в останній час на всіх кафедрах і курсах університету. Створено банк понад 300 контролюючих завдань 3 кожної теми до всіх змістових модулів. Із них кожному студенту згідно з існуючою програмою, методом автоматичного відбору, пропонується відповісти на 24 питання. Питання сформульовані таким чином: дві третини становлять тестові завдання, одну третину - ситуаційні задачі типу “Крок-2" та задачі з малюнками (рентгенограми, томограми, кардіограми тощо). Комп’ютер автоматично визна-

\section{Література}

1. Вакарчук I. Вища освіта України. Свропейський вимір: стан, проблеми, перспективи / I. Вакарчук // Вища школа. -2008. - № 3. - С. 3-19.

2. Вища освіта України і Болонський процес : навчальний посібник / за ред. В. Г. Кременя. - Тернопіль : Навчальна книга - Богдан, 2004.

3. Знаенко Н. С. Самостоятельная работа как средство организации познавательной деятельности / Н. С. Знаенко, И. В. Коноплева // Тезисы научно-методической конференции "Современные технологии учебного процесса в вузе”. - Ульяновск, 2008. - С. 5. чає правильність даних відповідей. Таким чином, зазначена методика забезпечує керовану викладачем дистанційну роботу студента. Студент у свою чергу має можливість оцінити ефективність ії виконання, переглянувши всі свої правильні та неправильні відповіді на моніторі комп'ютера.

Безпосередньо в клініці студенти за консультативної участі викладача навчаються клінічно мислити і діагностувати захворювання. На сьогодні студенти активно впроваджують у практику комунікативні навички. Першим кроком $є$ виконання діагностичних і практичних навичок безпосередньо біля ліжка хворого - збір скарг, анамнезу захворювання та життя, оволодіння методикою об'єктивного обстеження пацієнта. Наступним етапом є розвиток творчого мислення студентів - вміння нестандартного, індивідуального підходу до пацієнта, а також вміння відчувати страждання і біль хворого. Другий етап - це обговорення клінічної ситуації і останній -загальний підсумок із застосуванням тестового контролю набутих студентом знань та умінь.

Висновки: 1. Нові технології, що впроваджені на кафедрі внутрішньої медицини № 1, дозволяють удосконалити роботу студентів, тому що поєднують різні форми і методи як навчання, так і контролю навчання, а також впливають на різні сфери пізнавальної діяльності.

2. Інтранет-технології дозволяють своєчасно і самостійно опрацювати великий обсяг інформації за умов кредитно-модульної системи навчання, розвивати творче мислення і оволодівання практичними навичками.

4. Ковальчук Л. Я. Удосконалення самостійної роботи студентів - необхідна умова реалізації ідей Болонського процесу / Л. Я. Ковальчук // Галицький лікарський вісник. -2008. - Т. 15, № 1. - С. 79-81.

5. Коменский Я. Великая дидактика / Я. Коменский // Избр. пед. сочинения. Т.1.-М. : Педагогика, 1982. -350 с.

6. Коряковцева Н. Ф. Автономия учащегося в процессе изучения иностранного языка и культуры / Н. Ф. Коряковцева // Автономность в практике обучения иностранным языкам и культурам : сборник научных трудов МГЛУ. М., 2001.-Вып. 461.-С. 12-28.

Отримано 17.04.14 